\title{
Ostrich farming and environmental management tools: an overview
}

\author{
G. S. Rodrigues ${ }^{\mathrm{A}, \mathrm{D}}$, C. C. de A. Buschinelli ${ }^{\mathrm{B}}$ and L. R. Muniz ${ }^{\mathrm{C}}$ \\ AEmbrapa Labex Europe/Unité Propre de Recherche 34, Performance des Systèmes de culture de \\ plantes pérennes, CIRAD-PerSyst, Avenue Agropolis, 34398 Montpellier Cedex 5, France. \\ BEmbrapa Environment, CxP 069, Jaguariúna, SP, CEP 13820000, Brazil. \\ CFECOAVESTRUZ-Sudeste/ACAB, Praça Doutor João Mendes 52, Conjunto 502, Sao Paolo, CEP \\ 01501-000, Brazil. \\ DCorresponding author. Email: stacheti@cnpma.embrapa.br
}

\begin{abstract}
There is an increasing demand in the ostrich farming sector for management tools that are capable of motivating, preparing and guiding producers to meet the requirements of 'environmentally conscious' consumers. Many methodological options are currently available to conduct sustainability assessments and to ensure the best environmental management of rural activities. One option, the 'System for weighed environmental impact assessment of rural activities' (APOIA-NovoRural), has recently been validated for ostrich farming, as a tool for checking the contributions of the activity to local sustainable development. Case studies have favoured the understanding of the main environmental impacts and provided valuable recommendations regarding natural resources management and landscape ecology improvements in ostrich farming systems. Most importantly, the criteria and indicators constructed in this environmental management tool may be used for defining general 'Terms of Reference' for sustainable ostrich farming.
\end{abstract}

Additional keywords: struthioculture.

\section{Introduction}

A valuable marketing opportunity is currently in place for the ostrich farming business, owing to the environmental awareness of its consumers. Even if this special market opportunity has been well explored in value-added products and quality perception (Shanawany 1995), little attention has been directed in the literature towards environmental management practices and sustainability criteria specifically directed to the sector. For example, the most extensive ratite bibliography compiled to date (Ladd 1999) contains no references related to sustainable farming. One study only reports on the natural environment, regarding the effects of harvesting wild animals. Just marginal reference is made in the review to animal welfare, while the considerably numerous references to 'the environment' were actually related to factors for growth, diseases, and birds' behaviour in captivity. It is evident that environmental management in ratite farming systems (i.e. as a sustainability objective) was not an important research objective at the time the review was published, less than a decade ago.

By contrast, important social responsibility issues related to animal welfare in Europe have been recently reviewed (Carbajo 2007). However subjective the concept of animal welfare may be, a series of 'Codes of Animal Husbandry Practice' have been adapted to ostrich production. In general, these include:

(i) animal psychological freedom (to not suffer from confinement conditions);

(ii) behavioural or ethological freedom (to be able to express all forms of natural behaviour); (iii) physiological freedom (to not suffer from shortage of food or water);

(iv) environmental freedom (to be provided safe and proper facilities);

(v) absence of pain (to avoid unjustified pain, suffering or injury); and

(vi) absence of injury or disease (that is, the guarantee of good health).

The regulations of the European Union on animal welfare can only be complied with if all personnel involved in ratite farming are trained and made familiar with the terms of EU Directive 98/58 and its annexes (Carbajo 2007). Clearly, all legal and regulatory aspects (e.g. those concerning animal welfare, sanitation, biosafety, infrastructure and farm accessibility, among others) must precede every undertaking addressing specific environmental management directives. Once these mandatory aspects have been dealt with, as is the case for most ostrich farming regions (Carbajo 2006), issues concerning environmental quality and pollution prevention, energy efficiency, greenhouse gas emissions and the general objectives of sustainable development can (and should) be addressed.

The potential of ostrich farming to contribute towards sustainable rural development has been considered in a feasibility study on farm diversification as a means of fostering integrated rural development in less favoured European countries (LSIRD 1999). This geographically focussed feasibility proposal stems from a better capacity of these countries to profit from the 
broad range of value-adding alternatives offered by ostrich farming, in order to create a sustainable and productive industry. The research component was emphasised in the report, stressing the assessment of environmental factors affecting animal welfare and growth conditions, and the management practices employed in production to meet the high expectations of consumers (LSIRD 1999).

Both these aspects, namely environmental adequacy and high consumer standards, were appraised in a life cycle assessment of ostrich meat production, including the stages of feed production, transport, breeding and slaughtering (Nuñez et al. 2005). Consumer environmental awareness was a primary parameter considered in this assessment's critical analysis, which pointed out increased impacts of ostrich as related to beef and pork production. The purely comparative nature of the study, however, renders it impossible to gauge the local influences of different productive stages and associated practices (Foster et al. 2006), or the indirect and secondary impacts, such as those related to the choice of feed and forage.

For instance, where the nutrient-dense forage required by the birds can be produced by adequately managed, intensive and water-efficient crops (Greenwood et al. 2008) or by nitrogen fixing legume crops such as alfalfa (BDOA 2006), agriculture-livestock integration favours farm diversification, as proposed in the LSIRD (1999) feasibility report. The choice of feeding strategy will influence the potential of the farming operations to emit greenhouse gases, and the careful recycling of manures to fertilise crops and grasslands is considered a most suitable and cost-effective way for environmentally friendly disposal (van der Meer 2008). Extreme care must be taken, however, to avoid nitrate leaching and ammonia volatilisation (van Groenigen et al. 2008).

These aforementioned reports represent a modest, even if commendable, effort to address some of the sustainability and environmental management issues in ostrich farming. In order to fill this gap, a collaborative research initiative has been undertaken by the Federation of Cooperatives of Ostrich Producers of South-eastern Brazil (FECOAVESTRUZ-Sudeste) and Embrapa Environment (a Unity of the Brazilian Agency for Agricultural Research). The study addressed the socioenvironmental impacts of a broad range of ostrich farming operations, from small scale family farms, to large scale ranching, to specialised incubation enterprises. This comprehensive study applied a two-tier approach for sustainability assessment: (i) a technician training and farmer motivation program for ecocertification, and (ii) an impact assessment study directed at promoting the environmental management of ostrich farming in the region (Rodrigues et al. 2007).

In what follows, this study's methodological approach and results are overviewed and critically analysed, in order to examine their applicability as an environmental management tool for motivating, preparing and guiding producers towards best environmental practices for ostrich farming.

\section{Proposed methodology for sustainability assessment and environmental management in ostrich farming}

Among the possible alternatives to carry out socioenvironmental impact assessments of rural activities, the use of ecological and social indicators is a method of choice (Bosshard
2000). Ideally, the indicators are organised in 'Impact Assessment Systems' that may span increasing levels of complexity and goal requirements for environmental management (Monteiro and Rodrigues 2006).

A 'System for weighed environmental impact assessment of rural activities' (APOIA-NovoRural ${ }^{1}$, referred to herein as the 'APOIA-NovoRural System'; Rodrigues and Campanhola 2003) has been introduced for the environmental management of ostrich farming. The APOIA-NovoRural System integrates 62 indicators in five sustainability dimensions: (i) landscape ecology, (ii) environmental quality (atmosphere, water, and soil), (iii) socio-cultural values, (iv) economic values, and (v) management and administration. The rural establishment is the spatial scale of analysis, which is performed by objectively and quantitatively assessing the effects of farming operations, according to appropriate weighing factors (Rodrigues and Moreira-Viñas 2007).

The APOIA-NovoRural System indicators were constructed from a literature review of environmental impact assessment methodologies (Dee et al. 1973; Canter and Hill 1979; Neher 1992; Bockstaller et al. 1997; Smith and McDonald 1998; Girardin et al. 1999; Bosshard 2000; Rossi and Nota 2000; Monteiro and Rodrigues 2006), expert group discussions and workshops, followed by validation studies carried out for several rural activities and diversified environmental conditions (Rodrigues et al. 2006). Table 1 shows the complete set of indicators of the APOIA-NovoRural System, with their respective measurement units sought out in field sampling and laboratory analyses.

The data required for filling out many of the indicators' scaling checklists consist of administrative knowledge of the farmer, and are easily obtained in a field survey and/or interview supported by a structured questionnaire. Other indicators, related to soil and water quality, are obtained by field and laboratory instrumental analyses. All indicator scaling checklists include appropriate weighing factors that translate the indicator variables and attributes into a utility function, normalised from 0 to 1 , with the conformity level set at 0.7 (Fig. 1; Bisset 1987).

The utility functions express the environmental performance benchmarks for each particular indicator, and were derived from sensitivity and probability tests (Girardin et al. 1999), case-bycase for each indicator. In the probability test, one defines the limits of scale (maximum and minimum) and the compliance value $(0.7)$ for the indicator, according to trial-and-error numerical resolution of the indicator index (in the present case, sum of exposed workers/total number of workers). In the sensitivity test, one defines the meaning of the change brought about by the evaluated activity, its direction (whether positive or negative) and its quantitative relationship to an established performance baseline, according to defined benchmarks.

These tests allow the construction of a table of correspondence between the indicator index (IOccupS) and the utility values, which are then shown graphically in Fig. 1. A best fit equation was calculated for the correspondence relationship resulting in the expression of the impact index in utility values $(\mathrm{U}-\mathrm{IOccupS}$, in the present case $=0.85)$. The results obtained

\footnotetext{
'The APOIA-NovoRural System spreadsheets can be made available by a request to the authors
} 
Table 1. Landscape ecology, environmental quality, socio-cultural values, economic values and management and administration dimensions, with respective indicators integrated in the 'Weighed environmental impact assessment system for rural activities' (APOIA-NovoRural), and specific measurement units

Indicators

Measurement units for field and laboratory data

1. Structure and conservation state of natural habitats

2. Diversity and management condition of productive areas

3. Diversity and management condition of confined activities (agricultural/ non-agricultural and animal confinement)

4. Compliance with minimum preserved area requirements

5. Compliance with preservation of designated areas

6. Fauna corridors

7. Landscape diversity

8. Productive diversity

9. Reclamation of degraded areas

10. Incidence of endemic disease sources

11. Local extinction risk of endangered species

12. Fire hazard

13. Geotechnical hazards

\section{Atmosphere}

14. Suspended particles/smoke

15. Foul odours

16. Noise

17. Carbon oxide emissions

18. Sulfur oxide emissions

19. Nitrogen oxide emissions

20. Hydrocarbon emissions

Water

21. Dissolved oxygen

22. Coliform count

23. $\mathrm{BOD}_{5}$

24. $\mathrm{pH}$

25. Nitrate

26. Phosphate

27. Total suspended solids

28. Chlorophyll a

29. Conductivity

30. Visual water pollution

31. Pesticides potential impact

Groundwater

32. Coliform count

33. Nitrate

34. Conductivity

Soil

35. Soil organic matter content

36. $\mathrm{pH}$

37. $\mathrm{P}$ resin

38. K exchangeable

39. $\mathrm{Mg}$ (e Ca) exchangeable

40. Potential acidity $(\mathrm{H}+\mathrm{Al})$

41. Sum of cations

42. Cation exchange capacity (CEC)

43. Cation saturation

44. Erosion potential

45. Access to education

46. Access to basic services

47. Consumption standards

\section{Landscape ecology dimension}

Percent area of the establishment

Percent area of the establishment

Percent income of the establishment, excluded non-confined activities

Percent of the area of the establishment officially designated as preserve Percent area of the establishment

Preserve area (ha) and number of fragments

Shannon-Wiener index (calculated)

Shannon-Wiener index (calculated)

Percent area of the establishment

Number of sources

Number and status of (sub)populations

Percent of the area under risk

Number of influenced areas

II. Environmental quality dimension

Percent of time with occurrence Percent of time with occurrence Percent of time with occurrence Percent of time with occurrence Percent of time with occurrence Percent of time with occurrence Percent of time with occurrence

Percent $\mathrm{O}_{2}$ saturation

Number of colonies $/ 100 \mathrm{~mL}$

Milligram/litre de $\mathrm{O}_{2}$

$\mathrm{pH}$

Milligram $\mathrm{NO}_{3}$ /litre

Milligram $\mathrm{P}_{2} \mathrm{O}_{5}$ /litre

Milligram suspended solids/litre

Microgram chlorophyll/litre

Micro ohm $/ \mathrm{cm}$

Percent of time with occurrence

Percent of treated area

Number of colonies/100 mL

Milligram $\mathrm{NO}_{3} /$ litre

Micro ohm $/ \mathrm{cm}$

Percent organic matter content

$\mathrm{pH}$

Milligram $\mathrm{P} / \mathrm{dm}^{3}$

Millimole of charge $/ \mathrm{dm}^{3}$

Millimole of charge $/ \mathrm{dm}^{3}$

Millimole of charge $/ \mathrm{dm}^{3}$

Millimole of charge $/ \mathrm{dm}^{3}$

Millimole of charge $/ \mathrm{dm}^{3}$

Percent saturation

Percent of area of the establishment

III. Socio-cultural values dimension

Number of people

Access true or false ( 1 or 0 )

Access true or false ( 1 or 0 ) 
Table 2. continued

\begin{tabular}{ll}
\hline Indicators & Measurement units for field and laboratory data \\
\hline 48. Access to sports and leisure & Hours dedicated \\
49. Conservation of historic, artistic, archaeological, and speleological legacy & Number of monuments/events/sites \\
50. Quality of employment & Percent of workers \\
51. Occupational health and safety & Number of people exposed \\
52. Local opportunity for higher qualification employment & Percent of workers \\
& IV. Economic values dimension \\
53. Establishment net income & Tendency of attributes $(1$ or 0$)$ \\
54. Diversity of income sources & Proportional share of profit sources \\
55. Income distribution & Tendency of attributes $(1$ or 0$)$ \\
56. Current indebtedness level & Tendency of attributes $(1$ or 0$)$ \\
57. Establishment value status & Proportional share of value changes \\
58. Habitation quality & Proportional share of residents \\
& V. Management and administration dimension \\
59. Manager profile and dedication & Occurrence of attributes $(1$ or 0$)$ \\
60. Commercialization conditions & Occurrence of attributes $(1$ or 0$)$ \\
61. Residues recycling & Occurrence of attributes $(1$ or 0$)$ \\
62. Institutional relationships & Occurrence of attributes $(1$ or 0$)$
\end{tabular}

with the APOIA-NovoRural System are presented graphically in printable form, expressing the performance of the evaluated activity (in the present case, ostrich farming) for each one of the indicators, relative to the defined baseline. The results for all indicators are then combined by mean utility value for each dimension considered, composing a synthesis graph of impact for the five dimensions of sustainability considered and for the activity as a whole.

After all field and laboratory data are entered into de APOIA-NovoRural System spreadsheets, an 'Environmental management report' is formulated and issued to the farmer. This stresses recommendations of appropriate practices and technology adoption to minimise negative impacts and to promote positive ones, contributing towards the environmental management of the establishment.

\section{A case study of ostrich farming environmental management}

Aware of the importance of the environmental context for ostrich farming, FECOAVESTRUZ-Sudeste proposed the application of the APOIA-NovoRural System by a set of its associates. This was seen as a managerial tool for promoting their insertion in the national market, as well as preparing them for competing in the international scenario. The case studies were carried out in ostrich farming establishments selected as demonstration units.

\begin{tabular}{|c|c|c|c|c|c|c|c|c|c|c|c|c|}
\hline \multicolumn{13}{|c|}{ Table of number of people exposed } \\
\hline \multirow{2}{*}{\multicolumn{2}{|c|}{$\begin{array}{c}\text { Occupational } \\
\text { safety and health }\end{array}$}} & \multicolumn{5}{|c|}{ Peril factors } & \multicolumn{6}{|c|}{ Harm factors } \\
\hline & & $\begin{array}{r}\text { Source of } \\
\text { risk }\end{array}$ & 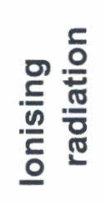 & $\begin{array}{l}\frac{8}{d} \\
\frac{x_{w}}{0} \\
\frac{0}{0} \\
\frac{x}{4}\end{array}$ & 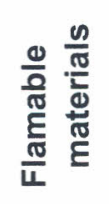 & 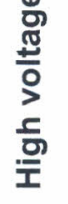 & $\frac{.0}{0}$ & $\begin{array}{l}\frac{c}{0} \\
\frac{0}{\pi} \\
\frac{0}{3} \\
\end{array}$ & $\begin{array}{l}\frac{0}{0} \\
\frac{0}{\pi} \\
\frac{\pi}{0} \\
\frac{0}{1}\end{array}$ & 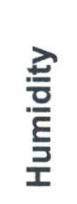 & 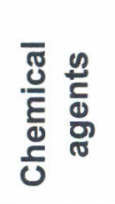 & 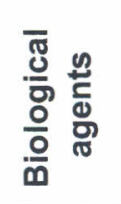 \\
\hline \multicolumn{13}{|c|}{ Total number of workers } \\
\hline \multicolumn{13}{|c|}{ Occupational safety index $=$} \\
\hline $\begin{array}{r}\text { IOccups } \\
10 \\
8 \\
6 \\
4 \\
2 \\
1 \\
0\end{array}$ & $\begin{array}{r}\text { Utility } \\
0 \\
0.1 \\
0.2 \\
0.4 \\
0.6 \\
0.8 \\
1.0\end{array}$ & ${ }_{0}$ & 2 & fety a & 6 health it & 8 & $\longrightarrow$ & $\begin{array}{l}\text { Ratior } \\
\text { Coeff } \\
a= \\
b= \\
c= \\
d= \\
\text { U-IOC }\end{array}$ & $\begin{array}{r}\text { st fit e } \\
\text { functio } \\
\text { ents: } \\
1.0 \\
-0.1 \\
0.1 \\
0.0 \\
\text { ups }=\end{array}$ & $\begin{array}{l}\text { juatic } \\
y=\end{array}$ & $\begin{array}{l}\text { n for uti } \\
a+b x) /(1\end{array}$ & $\begin{array}{l}\text { ity } \\
\left.+c x+d x^{2}\right)\end{array}$ \\
\hline
\end{tabular}

Fig. 1. Typical scaling checklist of the APOIA-NovoRural System, showing the occupational health and safety indicator. 
The results obtained in two selected ostrich farming operations are presented in Fig. 2. Both establishments reached impact indices above the benchmark compliance value defined in the method (0.70), indicating that ostrich farming has contributed favourably for sustainability in the studied situations.

In order to simplify the present explanation, from the set of 62 indicators, only those showing a particular contrast or an interesting convergence between the studied establishments are discussed, while the 'Environmental management reports' issued to the farmers emphasised every topic worthy of note for management decision making. The landscape ecology indicators in Establishment A (0.70) show the compliance observed regarding the requisites for habitat conservation defined in Brazilian legislation. In Establishment B, however, the legal requisites of Permanent Preservation Areas where not met, resulting in a lower index $(0.62)$. The results for the productive diversity indicator were very low for both establishments, because ostrich farming was the only relevant productive activity, indicating a risk for sustainability.

Water quality indicators were very much in contrast between the studied establishments. This was caused by high nitrate

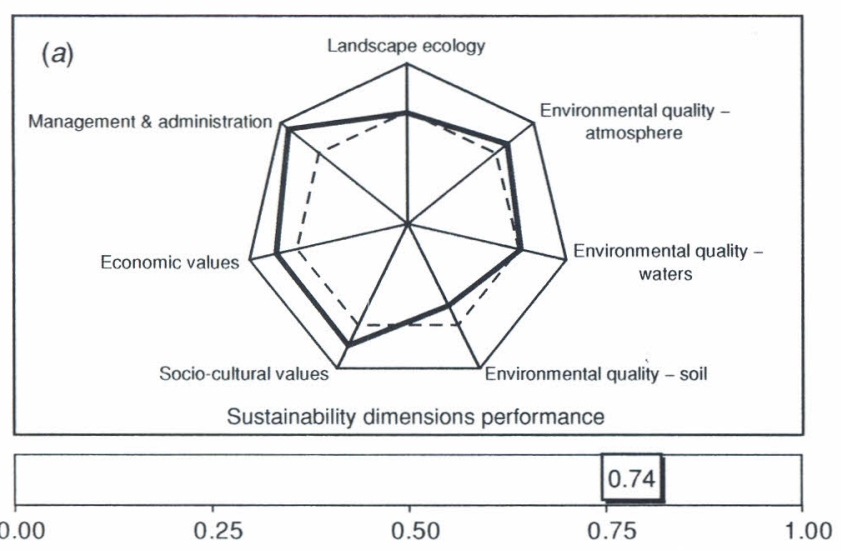

Rural establishment sustainability index

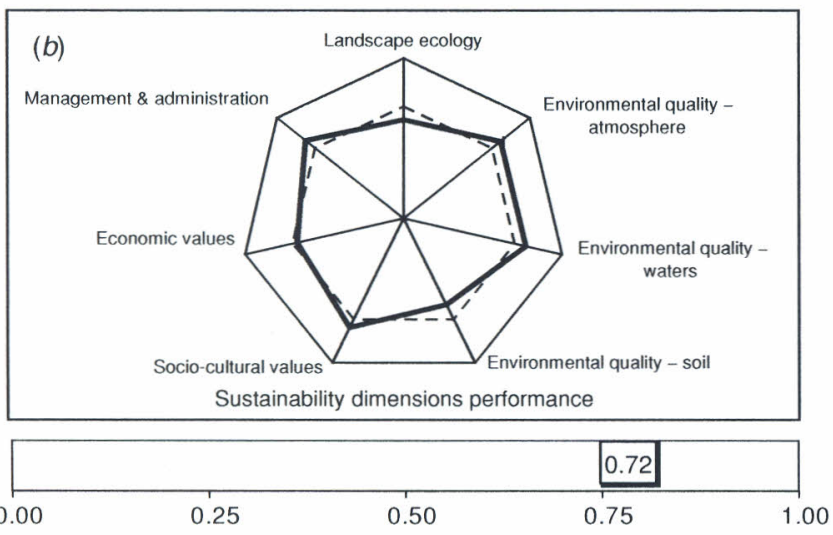

Rural establishment sustainability index

Fig. 2. Sustainability assessment results obtained with the APOIANovoRural System, for two selected ostrich farming establishments (A and B) in São Paulo State (Brazil). The dashed line on the graphs represents the 0.7 sustainability compliance baseline. Source: Rodrigues et al. (2007). levels and coliform bacteria presence in both surface and groundwater in Establishment A. Nitrate levels in groundwater of Establishment B were also high, but below the levels considered toxic for ostriches (Holle 2002). Despite these low results for nitrate and coliform indicators, the general water quality index was above the quality compliance value $(0.70)$ for both establishments. This indicates adequate management of the erosion in the plots and accesses, as well as good control of effluent emissions.

The results for soil quality indicators were below the compliance value baseline, denoting low soil fertility in both establishments (Fig. 2). In general, phosphate and potassium were deficient in the soils. For Establishment B, losses in organic matter content within the plots where the ostriches were kept resulted in a lower soil quality index $(0.60)$, compared with Establishment A (0.64).

Very good results were obtained for all indicators of the economic values dimension for Establishment A (0.83). This reflects primarily the extended time since implementation of ostrich farming in this establishment (1996), its large scale of operations (around 2500 animals) and current favourable market insertion. In contrast, and mostly as a result of the starting phase of ostrich farming in Establishment B (operation begun in 2004), the income generation and the current indebtedness indicators showed low performance indices, resulting in a 0.67 mean index for the economic values dimension.

The socio-cultural values and the management and administration indicators were very much favoured with the implementation of ostrich farming in both studied establishments $(0.84$ and $0.94 ; 0.76$ and 0.78 , respectively, for Establishments A and B). Special reference must be made to the indicators for manager profile and dedication and institutional relationship, which attest the importance of managerial initiatives towards improving the performance of the productive activity.

The general sustainability indices obtained $(0.74$ and 0.72 , for Establishments A and B, respectively, Fig. 2) imply that ostrich farming has brought, overall, positive contributions to the studied establishments.

\section{Conclusions}

The APOIA-NovoRural System has been demonstrated to be a comprehensive method, sufficient for field assessments and environmental management of ostrich farming. The results regarding the performance of ostrich farming according to particular environmental indicators, as exemplified in the present study, offer a diagnostic tool for producers, pointing out how the activity complies with defined legal standards and benchmarks. Additionally, the indicators show a measurement of the relative variation and temporal tendency of the impacts imposed by the activity, pointing out courses of action for local sustainable management.

The APOIA-NovoRural 'sustainability index' can be proposed as a yardstick for environmental quality certification of ostrich farming, pursuant to the defined objectives of reconciling ecological integrity, economic vitality and sociocultural equity measures for local sustainable development. The current critical analysis of the application of this methodology suggests the suitability of the proposed set of indicators as a 
basis for defining appropriate 'Terms of Reference for sustainable ostrich farming'.

The environmental performances observed in the establishments overviewed in this paper should be considered just a motivational case, directed at promoting the sustainability of ostrich farming. It is truly up to the organised sector, the producers, their cooperatives and representatives to define the extent and scope of a sustainable ostrich farming initiative that can address the demands of an increasingly sophisticated market.

\section{Acknowledgements}

The sponsorship and institutional support offered by Embrapa Environment, FECOAVESTRUZ-Sudeste and the 'Associação de Criadores de Avestruzes do Brasil' (ACAB) were instrumental for this study. Special gratitude is due to the farmers and administrators Mr. Adair Ribeiro Jr. (Vereda dos Avestruzes, Corumbataí), Mr. Célio Santos (Cooperavestruz, Mogi das Cruzes), Mr. Flávio Henrique de Jesus (GFStruthio, Atibaia), Mr. Marco Antônio Ortega (Sítio Casa Nova, Mairinque), Mr. Marcos Neves (Criavestruz, Pereiras), Mr. Nelson Yutaka Ito (Fazenda Bagres, Mairinque), Mr. Rafael Lucien Tadeu Pereira (Retiro do Avestruz, Itatiba), Mr. Rogério Pascoal Filho and Mrs. Ananda Pascarelli (Terra Brasil Avestruz, Araçatuba), who graciously offered their time and experience.

\section{References}

BDOA (2006) So why do we farm ostrich? (British Domesticated Ostrich Association: Carlisle, UK) Available at http://www.ostrich.org.uk/ farming/why.html [Verified 22 July 2008]

Bisset R (1987) Methods for environmental impact assessment: a selective survey with case studies. In 'Environmental impact assessment for developing countries'. (Eds AK Biswas, Q Geping) pp. 3-64. (Tycooly International: London)

Bockstaller C, Girardin P, Van der Werf HMG (1997) Use of agro-ecological indicators for the evaluation of farming systems. European Journal of Agronomy 7, 261-270. doi:10.1016/S1161-0301(97)00041-5

Bosshard A (2000) A methodology and terminology of sustainability assessment and its perspectives for rural planning. Agriculture Ecosystems \& Environment 77, 29 41. doi:10.1016/S0167-8809(99) 00090-0

Canter LW, Hill GL (1979) 'Handbook of variables for environmental impact assessment.' (Ann Arbor Science Publishers Inc.: Ann Arbor, MI)

Carbajo E (2006) Ostrich production to mature in more countries. 3rd International Ratite Science Symposium, Madrid. World Poultry 22, 24-26.

Carbajo E (2007) Protection of animals and EU regulation (dir.98/58 Ec): applied knowledge to ostrich. In 'Proceedings of the XIV World Ostrich Congress, Vol. 8'. p. 22.

Dee N, Baker J, Drobny N, Duke K, Whitman I, Fahringer D (1973) An environmental evaluation system for water resource planning. Water Resources Research 9, 523-535. doi:10.1029/WR009i003p00523

Foster C, Green K, Bleda M, Dewick P, Evans B, Flynn A, Mylan J (2006) Environmental impacts of food production and consumption: a report to the Department for Environment, Food and Rural Affairs. Manchester Business School, Defra, London

Girardin P, Bockstaller C, Van der Werf H (1999) Indicators: tools to evaluate the environmental impacts of farming systems. Journal of Sustainable Agriculture 13, 5-21. doi:10.1300/J064v13n04_03

Greenwood KL, Mundy N, Kelly KB (2008) On-farm measurement of the water use and productivity of maize. Australian Journal of Experimental Agriculture 48, 274-284. doi:10.1071/EA06094
Holle D (2002) Water quality for ostriches. In 'Blue Mountain ostrich nutrition. Bulletin No. 78’. (Blue Mountain Ostrich Feeds: Berthoud, CO) Available at http://www.blue-mountain.net/bulletin/bull78.htm [Verified 22 July 2008]

Ladd K (1999) Ratites bibliography. In 'University of Saskatchewan ratite bibliography and database'. Available at http://homepage.usask.ca/ $\sim$ kf1094/rat_all.htm [Verified 22 July 2008]

LSIRD (1999) Opportunities for species diversification for farm and environmental management: three European feasibility studies. (Macaulay Land Use Research Institute: Craigiebuckler, UK) Available at http://www.macaulay.ac.uk/livestocksystems/feasibility/introfeas.pdf [Verified 22 July 2008]

Monteiro RC, Rodrigues, GS (2006) A system of integrated indicators for socio-environmental assessment and eco-certification in agriculture Ambitec-Agro. Journal of Technology Management and Innovation $\mathbf{1}$, $47-59$

Neher D (1992) Ecological sustainability in agricultural systems: definition and measurement. Journal of Sustainable Agriculture 2, 51-61. doi:10.1300/J064v02n03_05

Nuñez Y, Fermoso J, Garcia N, Irusta R (2005) Comparative life cycle assessment of beef, pork and ostrich meat: a critical point of view. International Journal of Agricultural Resources Governance and Ecology 4, 140-151

Rodrigues GS, Campanhola C (2003) Sistema integrado de avaliação de impacto ambiental aplicado a atividades do Novo Rural. Pesquisa Agropecuaria Brasileira 38, 445-451.

Rodrigues GS, Moreira-Viñas, A (2007) An environmental impact assessment system for responsible rural production in Uruguay. Journal of Technology Management and Innovation 2, 42-54.

Rodrigues GS, Campanhola C, Rodrigues IA, Frighetto RTS, Ramos Filho LO (2006) Gestão ambiental de atividades rurais: estudo de caso em agroturismo e agricultura orgânica. Agricultura em São Paulo 53, 17-31

Rodrigues GS, Buschinelli CCA, Rodrigues IA, Medeiros CB (2007) A collaborative research initiative for the environmental management of struthioculture. Brazilian Journal of Poultry Sciences 9, 221-228.

Rossi R, Nota D (2000) Nature and landscape production potentials of organic types of agriculture: a check of evaluation criteria and parameters in two Tuscan farm-landscapes. Agriculture Ecosystems \& Environment 77, 53-64. doi:10.1016/S0167-8809(99)00092-4

Shanawany, MM (1995) Recent developments in ostrich farming. World Animal Review 83, 3-8.

Smith CS, McDonald GT (1998) Assessing the sustainability of agriculture at the planning stage. Journal of Environmental Management 52, 15-37. doi:10.1006/jema.1997.0162

van der Meer HG (2008) Optimising manure management for GHG outcomes. Australian Journal of Experimental Agriculture 48, 38-45. doi:10.1071/EA07214

van Groenigen JW, Schils RLM, Velthof GL, Kuikman PJ, Oudendag DA, Oenema O (2008) Mitigation strategies for greenhouse gas emissions from animal production systems: synergy between measuring and modeling at different scales. Australian Journal of Experimental Agriculture 48, 46 -53. doi:10.1071/EA07197

Manuscript received 13 April 2008, accepted 3 July 2008 